\title{
THE ROLE OF DECISION SUPPORT SYSTEMS (DSS) IN THE OPTIMIZATION OF PUBLIC SECTOR MANAGEMENT
}

\author{
Adelina Dumitrescu Peculea ${ }^{1 \star}$, Razvan Ion Chitescu ${ }^{2}$ \\ ${ }^{1}$ National University of Political Studies and Public Administration, Centre of European Studies, \\ 30A Expozitiei Street, Bucharest, Romania \\ ${ }^{2}$ National University of Political Studies and Public Administration, Strada Povernei 6, Bucharest, Romania
}

\section{Abstract:}

Due to major changes in the social, economic and political context over the past few decades, the Romanian public institutions require dynamic flexibility of the course of reforms and professionalization of structures. These are based on the adoption of important decisions and their efficient and proper implementation. In this context, decision-making becomes an important feature of the management process, beset by an increasing amount of information. Such avalanche of data, information and knowledge superimposed with a strong evolutionary internal and external environment, requires a dedicated information system, integrated and based on the controlled information flow and computer assistance. The conjugation between intuitive human judgment and decision-making may be far from optimal and deteriorate further in complex and stressful circumstances. The quality of decisions is important, and therefore, supporting of shortcomings of human judgment and decision-making was a major concern of science over time. The Decision Support Systems (DSS) can reduce human cognitive deficiencies by integrating various sources of information, providing intelligent access to relevant knowledge and supporting the decision-making process. These systems are intended for all kinds of managers and should help them to overcome their knowledge limits. The study herein presented is based on the analysis of the responses that constitute the matrix interview adjusted to the assumed theme. The research aims to analyse the role that the decision support systems have in the decision-making process in order to optimize public sector management.
\end{abstract}

\section{Key words:}

Decision Support Systems, public institutions, optimization, managerial process.

\section{INTRODUCTION}

Having in mind an extremely dynamic, complex and constantly evolving economy, the optimization of the decision-making process used for achievement of the performances concerns both management practitioners and researchers. The importance of the management process and optimization of the activities performed are crucial for development of organizations as society evolves and public administration is forced to adapt to the current social changes (Dumitrescu \& Dumitrescu-Peculea, 2014) and manage the available resources in an efficient, effective and cost-effective manner (the Strategy for public administration consolidation, 2014-2020). Moreover, we notice the implementation of reforms at the level of Romanian public institutions by "reinventing public administration" (Osborn \& Gaebler, 1992), creating a sustainable public administration, which has shifted within the last 25 years from intention beyond a desire towards a need, which has currently become a need included in all development strategies (European Commission, 2010). Therefore, we need transparent decision-making mechanisms, proper management of the available, often insufficient resources and appropriate administrative institutional structures, aimed at promoting the public interest (Pollit, 2003; Duțu \& Bogzeanu, 2010).

The quality of these decisions is also a result of the management, processing and exploiting large amounts of data, information, resulting from the internal area of an organization, as well as outside this organization. In terms of this substantial data flow, the data analysis has exceeded human limitations. Therefore, development of an information system that allows an efficient data management used for supporting the decision-making process becomes an imperative. This type of advanced system conveys the data immediately, directly, summarizes it, highlights the relevant data, and it is able to perform the analysis and make forecasts. 


\section{LITERATURE REVIEW}

Having considered an information system that facilitates the management process, regardless of the decisional level involved, its purpose is to provide support to adopting the most effective decisions, with the continuous aim of ensuring the performance of the organization. Although we are talking about a system which can be placed in a maturing phase, this is part of the managers' concerns and options, especially due to the integration characteristics of information and communication technologies, being integrated in the global information system of the organization.

The first definition for DSS was given by Little, in 1970, as "a model based on a set of data processing mathematical procedures meant to support a manager in the decision-making process" (Little, 1970). To make the actions taken more effectively, this system must be simple, adaptable and flexible in the communication of information.

25 years later, Turban (1995) defines DSS as "an interactive, flexible and adaptable computer-based information system especially developed for supporting the solution to a specific unstructured management problem. It uses data, supplied by a user-friendly interface and takes into account its own decision" (Turban, 1995:67).

Currently, Istudor views them as: "An integrated information system especially developed for the decisional process aimed at managers. It is an integrated part of an information management system, but differs from the information system for managers, since its main function is not limited only to the supply of information, but it also supplies the necessary analysis instructions for making decisions. It consists of a package of programs, one or several internal or external databases, as well as a knowledge base. It uses a language and a modelling program that allows managers to exploit various hypotheses and to assess the consequences" (Istudor, 2013).

In the light of the above given definitions, we consider that DSS is characterized by a series of specifications, with the aim of acquiring diverse knowledge about the decision maker's actions in order to be able to provide the basic elements at any given time. Moreover, it is important to notice their capacity to collect, manage and process information, procedures or rules, the possibility of presenting the results of the analysis in a synthetic manner, periodically but also the possibility of presenting the means of access, through direct and flexible interaction with the user/decision maker. Nevertheless, DSS provides the support in making decisions, without substituting human judgment, a judgement influenced by factors perceptible beyond the senses - internally or externally, although there are conditions of complexity, a very high volume of data or a rich set of requirements.

A new tendency encountered in the specialized literature refers to cognitive driven decision support systems in which the decision maker becomes an integrated part of the system, communicating in a natural language.

As any information system, the analysis of DSS also takes into account possible limitations. These cannot reproduce human behaviour such as imagination, creativity, intuition, they have a high cost of implementation and maintenance, specific operations are necessary and, if an already existing system is integrated, problems of compatibility may appear. In the case of managers, the intensive use of DSS may determine the blocking of constructive, strategic thinking, by dependence to DSS and solutions generated by it.
After analyzing the aspects presented, it is easy to pinpoint the role of DSS, namely that of management and control of an organization. In general, in most situations, the aggregated data and historical data are more important than immediate, detailed data. An overall modelling and viewing of such data is necessary to facilitate complex analysis. For example, if we want to make a prediction, we need historical data, and the operational databases are conditioned by the storage of current information. Therefore, the main objectives of DSS are the rapid access to information, the high processing and analysis capacity achieved by a user-friendly interface and a flexible presentation, all placed in a decentralized multi-user environment.

On the other hand, the evolution in the DSS field is also conditioned by the appearance of new technologies in the field of data storage, processing and analysis of information, in light of developing "data warehouse" solutions, OLAP applications („On-Line Analytical Processing”), „Data Mining” and artificial intelligence technologies (expert systems and intelligent agents).

Having in mind the main characteristics of DSS, our aim is to conduct a study that highlights the following:

- the existence and role of DSS in Romanian public institutions;

- the need to adopt decision support system solutions and their importance at the management level;

- their importance in making decisions and the suggestions for the improvement and development of future DSS solutions through customization or generalization.

\section{RESEARCH METHODOLOGY}

During the scientific process, we have used the specific methodology of a focus-group analysis with the aim of testing several research assumptions. By completing the descriptive-conceptual method, the research is supported by a variety of techniques needed for the operating study in this field. It is worth noting that the focus-group is not a problemsolving group or a decision-making one (Patton, 2002:385), but a qualitative method of collecting results in the forms of: ideas, perceptions, feelings, associated values, reasons, preferences, suggestions (Chelcea, 2004). The reason for choosing this method is also based on the efficiency that this semistructured interview has in developing some conclusions.

The planning of the actions of this analysis was based on the organization of two groups of decision-markers in the public administration, who work in different management areas. The respondents were part of the central public and local administration. The division into groups was not influenced by age, sex, political affiliation. The attempt was made to minimize one of the limitations of the focus-group analysis, by which a group opinion leader is formed, who then decides the tendency of answers.

The number of participants is relatively small, 23 persons, of whom 7 women and 16 men. The general age level was approximately 38 years. The higher number of men in our study is justified by the high number of male managers in public administration, while the relatively low age level is due to the moderator, who decided to invite younger managers. The motivation is found in the reluctance of managers past a certain age to interact with an information system, 
their insufficient training in the field of information technology and their dependence on the obsolete management techniques and methodologies.

The education level of the persons interviewed was higher education in $100 \%$ of cases. It was noticed that the education level of the majority was not finished after university graduation, but there are cases of post-graduate studies, specialized professional training or unitary or regular specialization courses. The surprising fact about this analysis was that the majority of the persons presented attended these courses without any obligation imposed by the institution they were part of, without any financial aid or time resources. The majority of these courses were taken after work, with additional costs, without immediate remunerative or motivational rewards, but with clear benefits for the institution.

The participation to talks by the persons invited, in both groups, was open, focused on the subject proposed, the opinions were expressed freely. The limitations of our study represent the small number of participants, which prevents us from generalizing the conclusions at the level of the entire administration, and also the failure to recognize all institutions where a DSS solution was implemented, adopted or applied.

The discussion during this focus-group analysis was based on a matrix of questions, split into four categories, with a variable number of items for each category. The questions were formulated with the purpose of underlining the role that decision support systems have in supporting the manager's decisions, with the purpose of optimization of management in public institutions.

Due to the versatility of the activities, it is important to identify, on several decisional levels, the manager's perception of the quality of the decision and the efficiency of decisions made using DSS. Furthermore, pertinent conclusions can be drawn in order to develop DSS information solutions.

1. The interview matrix is based on three aspects, considered elementary, namely:

2. The existence and use of an integrated DD system informatics

3. The positive role of using a decision support system

The development of dedicated decision system support solutions and the implementation of these solutions in the public administration system.

The aim of the paper is to test several research assumptions, validate or invalidate them. Therefore, the following research assumptions have been identified:

H1: For the optimization of processes, the managers of Romanian public institutions use decision support systems.

H2: There is a direct and positive influence on the decision by using DSS.

H3: All management decisions of decision support systems must be supported.

\section{RESULTS AND DISCUSSION}

Using the results of the study for a qualitative analysis, after talks, the following conclusions were drawn:

The first aspect of the interview matrix was focused on a set of questions whose essential purpose was to participate in identifying DSS solutions implemented in implemented in the institutions where they operate. In this case, the re- spondents' answers are not homogenous. For managers who have a low decisional power, the existence of these decision support systems is not very obvious. Especially in fields such as the defence system - in which descendent communication has the attributes of orders and must be fulfilled to a $\mathrm{T}-$-, decision support systems are not very visible. There is a growing awareness of their existence, their role in summarizing the large volume of data is clear, but there is no real, practical interaction with a system informatics. This opinion is also shared by managers who, in their mission, conduct a field work or a very well defined work that lacks any information support. When it comes to higher level managers, the situation is different. They know whether there are decision support systems or not - most of the time there are solutions that they have requested in order to support the activity of the institution, while the technical solutions adopted are exactly development of the approved necessity studies. By analysing the managers of the same institutions but on different decisional levels, in addition to our study, a lack of vertical communication is noticed, especially regarding the descendent communication flow and the non-involvement of all the factors involved, in adopting solutions. The results of the analysis of this pillar allows us to conclude that decision support systems are used at the higher management level, with the limitations imposed by the particular business development context.

Also, figures below show the implementation degree of SSD in public institutions.

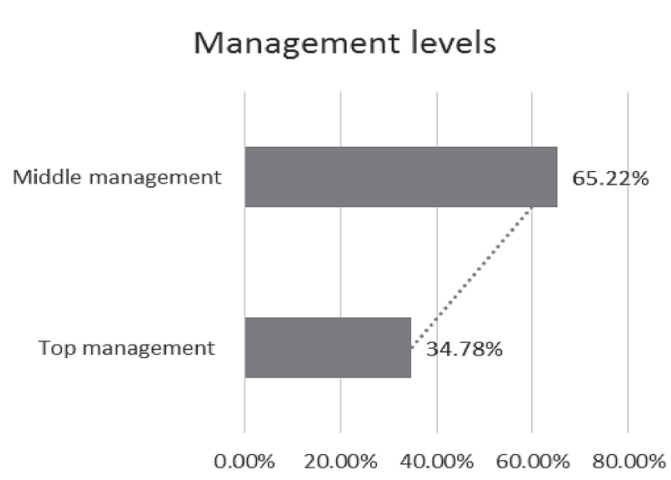

Figure 1. Level of participating managers taking part in the focus group

\section{SSD implementation in public institutions}

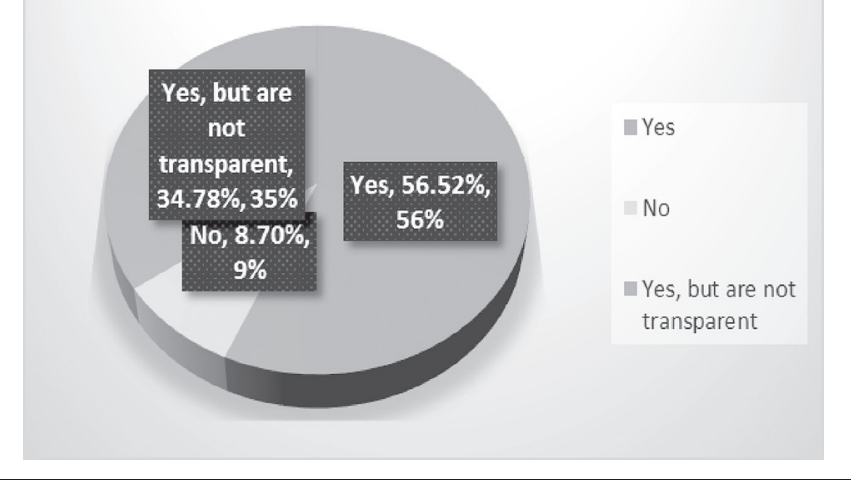

Figure 2. SSD implementation in organizations Source: based on interpretation of focus group results. 
During the decision-making activity, a higher manager must take into account several variables. The questions from the second pillar of the matrix have attracted the greatest attention among the persons interviewed and allowed the majority of the respondents to express their opinion. Not all the opinions were objective. Nevertheless, the medium or lower level managers, those who did not actually interact with a system informatics dedicated to the adoption of solutions, were the ones who highlighted the practical aspects of the operation of this system. Therefore, these are the ones that better understand the importance of a database, the volume of information that must be managed, these are those that keep a system informatics and know the effects of a nonintegrated operation of certain systems, they are responsible for their fields of activity and, through horizontal communication, they are more aware of their role in the system and of the negative effects caused at the level of the entire system by incorrect operation of a segment. They are actually the main part of the information system. However, the higher level managers underline the effects of taking assisted decisions. They have an overview on the impact of such a decision. Moreover, they are well aware of the fact that the solution adopted is closer to reality, since it is grounded on a set of information processed by dedicated information systems. They are not very well aware of the volume of processed data or the time in which these were obtained. Certain systems have been developed or implemented in institutions precisely due to situations in which the manager was not able to adopt a decision based on the requested data.

There are also situations in which decisions made did not have positive results, but negative results which are not considered to have a direct relation with decision support systems, their operation or the data storage and processing capacity. Their positive role in the implementation of quality decisions is unanimously recognized.

The improvement of decision support systems was again a topic of discussion. However, the starting point was the high cost of acquisition of the equipment and software, regarding the high maintenance and development costs. Managers are reluctant to invest in information solutions because of the users' precarious information culture - we refer here to the entire chain of users, from the data operator to the manager. The reasons that emerged are the aging of the staff who work in public institutions, the absence of an effective training, the existence of data security reserves, the redundancy of certain employees as a result of the computerisation of certain services. The development of dedicated integrated solutions for managers is not only an attribute of end users, the manager, since the operation within certain parameters must also take into account the decisions of the specialists/collaborators across various fields. There are also technical or programming limitations that a manager must consider. Moreover, the interface used must be adjusted to the decision maker's understanding, the communication must be easy, and the interpretation of the requirements must be correctly deciphered by this system. There are cases in which higher level managers invoke a decisional pressure, even though assisted, under conditions in which there are no intermediate decisional levels, the entire responsibility falls on their shoulders.

Among the topics discussed during these meetings, the topic of the limitations of the decision support systems was discussed as well. It is considered that the development of these systems is carried out according to needs of every institution and the management policy adopted. Thus, they can be customized depending on the particularities of the activity that must be developed, the needs of analysis, storage, management and interface accepted and used by the manager. The limitations are only ethnical, since there are financial constraints that require a certain quality, configuration, maintenance that do not allow a correct or logical development. All these may lead to the limitation of the specific functions or an inefficient interaction with the rest of the information system, which might generate material or informative errors. The situations, in which management decisions cannot be made merely on the basis of certain interpretations of mathematical models, require the presence of experts, i.e., people who have solid specialized knowledge, a high power of judgment and a vast experience in solving complex problems.

The results of the research confirm the assumptions made. Therefore, the existence of decision support systems in Romanian public institutions is clear as well as the fact that managers ground their decision making on its use. Moreover, the results of the study reveal the need to develop new DSS systems, dedicated to various specific activities, but also the implementation of these solutions at the medium-level management. The positive role of these systems in adopting best solutions in the given situations is indisputable. Nevertheless, the bases of effective as well as ineffective solutions are not these systems but the manager's intuitive analysis, as well as the analytical analysis, based on studies, forecasts, predictions.

\section{CONCLUSIONS}

The DSS development environment has multidisciplinary grounds, including databases, man-computer communication, artificial intelligence, simulations, hardware and software development, telecommunications. The complexity of this context overlaps the dynamics of the external environment, that is to say its effervescence. The involvement of DSS in the adoption of decisions brings the benefits of multidisciplinary research and implicitly, an extended vision in every solution proposed, which leads to efficiency and success.

The complexity of the economic, social and political environment, corroborated with the effects that these environments have on the public administration, does not allow the identification in adopting decision support system solutions. Based on the very complex information systems, with the possibility of storage, processing of an impressive volume of data in a short time, the decision support systems have become an integrated and indispensable part of the quality management process. The professionalization of Romanian public institution and its adjustment to the European requirements as well as the optimization of financial, human and logistic resources of this segment require a large scale adoption of support solutions for the management.

The proposals for improvement of these integrated studies were based on the main characteristics of the DSS decision support solutions, primarily on the continuous attention to technical excellence, collaboration between program developers and managers, need for simplicity, carefully constructed system architecture and effective communication. 


\section{REFERENCES}

Cancelaria Primului Ministru, Ministerul Dezvoltarii Regionale si Administratiei Publice. (2014). Strategia pentru consolidarea administratiei publice 2014-2020, M.O., Partea I, Nr.834bis. Available at http://www.mdrap.ro/userfiles/strategie_adm_ publica.pdf.

Chelcea, S. (2004). Metodologia cercetării sociologice. Metode cantitative şi calitative. Bucureşti: Editura Economică.

Courbon, J.C. (1996). User-centered DSS design and implementation, Implementing Systems for Supporting Management Decisions: Concepts, Method and Experiences (pp. 108-123). London: Chapman \& Hall.

DeSanctis, G., \& Gallupe, R.B. (1987). A foundation for the study of group decision support systems. Management Science, 33(5), 589-609.

Dobrican, O. (2005). An example of collaborative system in The proceedings of the international workshop on Collaborative support systems in Business and Education, Cluj-Napoca.

Donovan, J.J., \& Madnick, S.E. (1977). Institutional and Ad-Hoc DSS and Their Effective Use. Available at http://portal.acm. org/citation.cfm?id=1017599

Dumitrescu, M., \& Dumitrescu-Peculea, A. (2014). Strategii și management. Dimensiuni socio-umane contemporane. București: Editura Economică.

Duțu, P., \& Bogzeanu, C. (2010). Interesele naționale şi folosirea instrumentelor de putere naţională pentru promovarea şi apărarea acestora. Cazul României, Editura Universității Naţionale de Apărare „Carol I”, Bucureşti.

European Commission. (2010). EUROPE 2020 - A strategy for smart, sustainable and inclusive growth. Brussels: European Commission.

Filip, F.G. (2004). Sisteme suport pentru decizii. București: Ed Tehnica.
Handley, H., \& Heacox, H. (2004). An Integrative Decision Space Model for Simulation of Cultural Differences in Human Decision-Making. Information Knowledge Systems Management, 4(2), 95-105. Available at http://dl.acm.org/citation.cfm?id=1234252

Istudor, I. (2013). Tendinte moderne in domeniul sistemelor suport pentru decizii. Revista Româna de Informatica si Automatica, 23(1), 5-12.

Le Saget, M. (1999). Managerul intuitiv o nouă forță. București: Editura Economică.

Little, J.O.C. (1970). Models and managers: the concept of a decision calculus. Management Science, 16(8), 446-485. doi: $10.1287 / \mathrm{mnsc} .1040 .0267$

Marakas, G. M. (2003). Decision support systems in the 21st century. Upper Saddle River, NJ: Prentice Hall.

Osborne, D., \& Gaebler, T. (1992). Reinventing government: How the entrepreneurial spirit is transforming the public sector. Reading, Mass: Addison-Wesley Pub. Co.

Patton, M.Q. (2003). Qualitative Research \& Evaluation Methods: Integrating Theory and Practice. Thousand Oaks, CA: Sage

Pollitt, C. (2003). Joined-up Government: a Survey. Political Studies Review, 1(1), 34-49. doi: 10.1111/1478-9299.00004

Rusu, E. (2001). Decizii optime în management prin metode ale cercetării operaționale, Editura Economică, Bucureşti.

Turban, E., \& Aronson, J.E. (2007). Decision Support Systems and Intelligent Systems, 8th ed. New Jersey: Prentice Hall.

Turban, E. (1995). Decision supportand expert systems: managementsupport systems. Englewood Cliffs, NJ: Prentice Hall.

Zamfirescu, C.B. (2003). An Agent-Oriented Approach for Supporting Self-Facilitation in Group, Decisions. Studies in Informatics and Control, 12(2), 137-148.

\section{ULOGA SISTEMA ZA PODRŠKU ODLUČIVANJU U OPTIMIZACIJI PROCESA UPRAVLJANJA JAVNIM SEKTOROM}

\section{Apstrakt:}

Usled velikih promena u društvenom, ekonomskom i političkom kontekstu tokom proteklih decenija, državne institucije u Rumuniji su primorane da razviju dinamičku fleksibilnost reformi i profesionalizaciju unutar svoje strukture. One su zasnovane na donošenju važnih odluka i njihovoj uspešnoj primeni. U tom kontekstu, donošenje odluka postaje važno obeležje upravljačkog procesa. Ogromna količina podataka, informacija i znanja u okruženju, zahteva namenske informacione sisteme, integrisane i zasnovane na kontrolisanom protoku informacija. Odnos između intuitivnog ljudskog rasuđivanja i odlučivanja može da bude daleko od optimalnog i pogoršava se u stresnim i kompleksnim okolnostima, te je stoga kvalitet procesa odlučivanja od presudnog značaja. Sistemi za podršku odlučivanju mogu da prikriju kognitivne nedostatke pojedinca integrisanjem različitih izvora informacija, kroz adekvatan pristup i neophodno znanje. Ovi sistemi namenjeni su menadžerima na svim pozcijama i pomažu im da prevaziđu granice sopstvenog znanja. Istraživanje ima za cilj da ispita ulogu koju ovi sistemi imaju u procesu donošenja odluka u cilju optimizacije procesa upravljanja javnim institucijama.

\section{Ključne reči:}

sistemi za podršku odlučivanju, javne institucije, optimizacija, upravljački proces. 